\title{
PERFORMING POLITICS IN THE AGE OF SOCIAL MEDIA: ENTERTAINMENT, INFORMATION AND GOVERNANCE
}

\author{
Azrina Husin \\ School of Social Sciences, Universiti Sains Malaysia, 11800 Penang, Malaysia \\ azrina@usm.my
}

\begin{abstract}
This paper discusses the way politics is performed in the age of social media through popular platforms such as Facebook and Twitter. While these platforms function as a site for networking and information sharing, these sites also contain a wealth of data about the users ready to be mined by any interested parties, be it for political or economic gains. This feature is a characteristic of the present world brought about by the Fourth Industrial Revolution. As the world is increasingly becoming online, traditional way of doing and performing politics, ranging from practicing politics to communicating about politics, has changed. The paper outlines five interrelated ways in which politics are now performed online and the implications to governance and democracy. Following the argument of Neil Postman on public discourse in the age of television, this paper argues that in the age of social media, politics is now performed not only in an entertaining manner, but social media has also encouraged speculations and uncertainties among its citizens. Thus, while the potential for social media is there to increase political participation among citizens, it also carries with it the danger of creating a mis-informed public despite the wealth of political information available.
\end{abstract}

Keywords: social media, Neil Postman, performing politics 
Proceeding ICOGISS 2019

Page 1-8. ISBN: 978-602-6 988-75-1

Web Jurnal Online: jurnal.unmuhjember.ac.id

By: Azrina Husin

Performing Politics In The Age Of Social Media:

Entertainment, Information And Governance

\section{INTRODUCTION}

The Fourth Industrial Revolution (4IR) is bringing about changes in the way we live, work, interact and experience our environment. At the same time it is also questioning our understanding of the physical (our here and now), digital (our levels of reality) and biological (our human race). The technologies of the 4IR-Internet of Things, Artificial Intelligence, the Digitalisation of Everything, Robotics, Big Data and cloud computing, to name a few-are advancing at the speed of light and the impacts are farreaching than ever before. These technology-led changes are disrupting and challenging our ways of thinking and doing. Despite the disruptions and destructive nature of the 4IR, we are also promised of many potentials that these technologies could bring to our lives. Yet, we are also cautioned about the unresolved problems such as inequality, accessibility, marginalization and alienation that will continue to be pressing in the new technology-led landscape we are living in (see for example Fuchs, 2018).

Within the context of 4IR, social media or social networking sites (SNS) is also undergoing its own revolution as shown by popular sites such as Facebook and Twitter. The popularity of these sites among users remains strong. With these changes, the way we use SNS has also altered the way we see ourselves, construct ourselves as well as communicate among ourselves. One such site, Twitter--a microblogging site that allows messages to be sent (tweet) and resent (re-tweet) to a large number of followers across the globe--recently revealed that it has 126 million daily active users and this number is expected to continue growing (Hamza, 2017). This increase also means that the number of tweets and re-tweets daily has also increased. Another popular SNS is Facebook which also reported an increase in the number of users globally, with 2.38 billion monthly active users in the first quarter of 2019 (Clement, 2019). Other recent sites such as Snapchat, Whatsapp and Instagram have also become increasingly popular among global users. In Malaysia, for example, a nationwide survey conducted by the Malaysian Communications and Multimedia Commission revealed many interesting findings pertaining to Malaysians' usage of the Internet. Among others, an increased number of Internet users from 2016 to 2018 (from $76.9 \%$ to $87.4 \%$ respectively), with most using mobile phones to engage in social activities as well as sharing and disseminating content. This scenario echoed the findings of another study that reported Malaysia as the highest mobile social media penetration in Southeast Asia and top 5 in the world (as cited in New Straits Times). Access to information as well as the ability to stay connected online has become a huge part of most Malaysians.

Developments in mobile connectivity has brought about efficiency and speed in the way users connect and communicate in these sites that started out as platforms for networking and staying connected with others. These sites also contain a wealth of data on users consisting not only personal information, but also users' preferences, lifestyles, locations, opinions and network through data in the form of shared and created contents via texts, images and videos. Thus, social media is a site for data mining for any interested parties, either for political or economic gains. Within the political context, this data is prime for use by the government or political parties and politicians to govern, 
Proceeding ICOGISS 2019

Page 1-8. ISBN: 978-602-6 988-75-1

Web Jurnal Online: jurnal.unmuhjember.ac.id

By: Azrina Husin

Performing Politics In The Age Of Social Media:

Entertainment, Information And Governance

control and manipulate users accordingly. Social media has changed the landscape of politics in terms of citizen participation and engagement, political communications as well as how politics is performed in today's increasingly online world we inhabit today.

\section{Social Media and Politics}

Social media such as Facebook and Twitter are powerful communication tools in at least two ways. One, social media is a user-centric communication tool that enable the users to create their own content in the form of written texts (for example to express their thoughts and opinions on Twitter and Facebook) or visuals (videos of their experiences or videos and pictures created by others that they have interests in, for example in YouTube or Instagram). These contents are then shared across the globe with their fellow online followers and friends. In this sense, users are active participants in the communication process, acting both as producers and receivers of contents. Two, social media enables instantaneous and far-reaching communication, creating a "global village" of "likeminded individuals" who share similar interests to engage and interact. Communications through social media are no longer constrained by schedules as it is in broadcasting or printed media. Thus, social media has changed the way we communicate, allowing for immediate communication that is multi-directional and no longer constrained by time and space. In the age of social media, information flows at a speed faster than before and in a quantity unimaginable before.

Users of the various social media platforms are not only ordinary people. Although many of the platforms started out as social networking sites for individuals to stay connected with friends, family and colleagues through online interaction, social media ability to share content and connect through time and space has turned these platforms into more than just personal communication platforms. Making full use of this, companies and institutions are also using these platforms to reach out to their target groups. Thus, celebrities are using Instagram and Twitter to show (and share parts of) their lives with their fans; media institutions have their own Facebook account to bring news immediately to their readers; companies open up online communication door to enable feedback from customers and potential clients; and Twitter and Facebook are used by political actors to reach out to their followers with constant and immediate online posts. In this way, social media has changed political communications in ways that allow for more engagement with voters, informing and mobilizing them directly, bypassing mainstream media. Political actors are more in control of their campaigns and have direct access to their voters. This is evident as early as during the 2008 US Presidential Election in Barack Obama's political campaign and his subsequent social media presence (see for example, Aaker and Chang 2010).

Social media platforms have created a public space, albeit online, where political issues are raised, discussed and debated by concerned citizens. Its open and collaborative nature allows for optimism towards political mobilization and participation. Benkler (2006), for example, argued that social media gave rise to networked public sphere and demoratizing communications. Papacharissi (2009), on the other hand, discussed how active citizens can voice out their dissent and dissatisfaction with public agenda by 
Proceeding ICOGISS 2019

Page 1-8. ISBN: 978-602-6 988-75-1

Web Jurnal Online: jurnal.unmuhjember.ac.id

By: Azrina Husin

Performing Politics In The Age Of Social Media:

Entertainment, Information And Governance

creating online contents and sharing them. Thus, these authors claimed that this development is a return of what Habermas (1991) termed public sphere--a public space open to all citizens to participate and form public opinion, which in turn is used to regulate and control state activities.

Social media has certainly changed today's political landscape. However, despite the optimism laid out by many scholars, we need to ask the following questions: Are users/citizens active participants in political discussions or are passive information receivers? With a lot of political information in circulation via these social media platforms, does this make citizens more informed? What is the nature of interaction between users and political actors in an online environment that does not rely on (and in fact at times, forgo) usual convention? Does social media communication that rely on short and entertaining texts as well as powerful visuals inform the public about public issues and agenda, ultimately creating an informed public? These questions then point to a need for a more critical look of politics as performed on social media--our dominant medium of today.

\section{Conceptualizing Performing Politics}

This paper defines "politics" broadly to include the activities revolving around governance, public discourse and public opinion, as well as political actors who engage in those said activities. These political actors are not only politicians or government officials, but also refer to formal institutions of governance and administrations, as well as the media institutions. The media institution, on the hand, has been traditionally regarded as the fourth estate for its role in framing issues and setting political agenda for the public.

Social media such as Facebook and Twitter has provided an online stage for political actors to engage in politics. Unlike offline stages accorded to politics (for example, traditional press and news station, political events, parliament), online stage has given more autonomy for political actors to decide and control the political messages (or any messages for that matter) that they want to send out. Organized as a one-to-many communication platforms, social media give political actors direct communication channel to their potential voters, at the same time making the communication feel personalized and one-to-one. Social media has thus created a sense of intimacy as well as informality between "leaders" and "followers", and between "those who govern" and "those who are governed". Media institutions with its own set of rules are no longer the only institutions that "make news". In fact, media institutions also maintain online presence in order to bring news to the people without the constraint of time. In addition, sources of news now also include social media postings, reported (with a twist) by reporters as news.

By looking at the way politics are being performed online via social media such as Facebook and Twitter by these actors, this paper seeks to argue that a sense of formality in doing politics - either in the form of politics-related news reporting or the online persona of political actors-has been eroded. Matters pertaining to politics as 
Proceeding ICOGISS 2019

Page 1-8. ISBN: 978-602-6 988-75-1

Web Jurnal Online: jurnal.unmuhjember.ac.id

By: Azrina Husin

Performing Politics In The Age Of Social Media:

Entertainment, Information And Governance

performed online has become informal, sensational, intimate, and immediate, thus, ultimately, in the words of Neil Postman (1985), entertaining.

\section{Ways Social Media Changed How Politics is Performed}

In response to some of the questions posed earlier, this paper outlined eight ways in which politics are performed on social media, taking into account its affordance for immediacy and personalized content. First, these online platforms have shifted the grounds on how political news is reported, received and discussed. Although not yet obsolete, mass media is making way for personalized media available on social media sites. In fact, these traditional media either in the form of television or print have to report news constantly to users via their online portals. News can no longer be delivered according to allocated time of broadcast and printing. While maintaining an online presence via these platforms, social media has also become one of the many sources of news for reporters nowadays, with tweets and posts from political figures on their own social media were taken and given a new slant to be reported on online media outlets. In fact, with the democratization of communication, reporters are competing with ordinary people to report news or the emerging "citizen journalists". A case in point is the way onsite ordinary people were able to post videos and commentaries during the New Zealand mosque attacks early this year. News-making has changed drastically from the time of Tuchman's account in her seminal work Making News: A Study in the Construction of Reality (1978), in terms of institutional values and constraints as well as what constitutes newsworthiness.

Second, related to the way social media platforms afford personalized content is the fact that users now are in control of the kind of information they want to consume and share. While traditional media is top-down in nature with audiences seen as passive receivers of news, consumers now can dictate the kinds of news, which media outlets as well as which political actors they want to follow. On the surface, this development is seen as empowering to the users who are now active content makers. However, despite hailing social media platforms as sites that encourage political participation and engagement, choosing political content that suits one's preference will eventually end up with one being informed in a one-dimensional manner. Thus, regardless of the amount of political information available online now, one is still at risk of being mis-informed. Viewed this way, social media platforms do not necessarily breed informed citizens which in turn is an essential ingredient for a democratic society.

Third, political actors now make themselves visible through their various social media platforms. At the same time informing their followers (and potential voters) their thoughts and opinions on public issues, social media is also used to present their more personal sides such as their daily routines, itineraries and hobbies that were obscured from the public prior to the existence of social media. The public is then allowed a glimpse of the lives of these political actors, giving a sense of false intimacy between politicians (public figures) and the public. Although this may be ways the political actors wish to document their lives, this can also be seen as a way to appeal to their followers by 
Proceeding ICOGISS 2019

Page 1-8. ISBN: 978-602-6 988-75-1

Web Jurnal Online: jurnal.unmuhjember.ac.id

By: Azrina Husin

Performing Politics In The Age Of Social Media:

Entertainment, Information And Governance

showing them that political actors lead a "normal" life just like everyone else. Fourth, Sunden (2003) argued that in order to have an online existence, one must write oneself into being by having profiles, texts, visuals that in many ways represent one's desired self. In the case of political actors, their less rigid online persona they have created offers room for less restricted interactions and engagement with their followers that may not be available in the real world. As such, online interactions may not always conform to the set of face-to-face interaction rules, allowing for less formalities. This can be seen in the language used in the comment section left by followers with many taking on a rather playful tone, or less bothered with correct grammar or spelling, as well as the use of emoticons to express their feelings. Political actors are also freed from formalities in the way they create their content. Donald Trump, an avid Twitter user, is infamous not only for the number of tweets he sends out but the nature of his tweets too.

Fifth, related to the informal way online interactions are carried out, in this age post literacy, the importance of visuals (images, videos) and short yet playful texts cannot be denied. Adding to the sense of intimacy that social media platforms created, images shared by political actors give a "real" sense of what is going on in their lives. Similarly, in order to engage with the followers, formal languages are sometimes dropped in favor of more informal and casual style of writing that is akin to casual conversations. These five ways in which politics are performed online have created a political communication that is less rigid, less constrained by understood norms and at the same time, allowing political actors to create and control their online persona.

\section{Concluding Notes: Bringing Neil Postman's Ideas to Social Media}

What Orwell feared were those who would ban books. What Huxley feared was that there would be no reason to ban a book, for there would be no one who wanted to read one. Orwell feared those who would deprive us of information. Huxley feared those who would give us so much that we would be reduced to passivity and egoism. Orwell feared that the truth would be concealed from us. Huxley feared the truth would be drowned in a sea of irrelevance. Orwell feared we would become a captive culture. Huxley feared we would become a trivial culture, preoccupied with some equivalent of the feelies, the orgy porgy, and the centrifugal bumblepuppy. As Huxley remarked in Brave New World Revisited, the civil libertarians and rationalists who are ever on the alert to oppose tyranny "failed to take into account man's almost infinite appetite for distractions." In 1984, Huxley added, people are controlled by inflicting pain. In Brave New World, they are controlled by inflicting pleasure. In short, Orwell feared that what we hate will ruin us. Huxley feared that what we love will ruin us. (Postman, 2005)

Focussing on the year 1984, Neil Postman compared two scenarios brought about technologies in two novels: George Orwell of the same title, and Adolf Huxley's A Brave New World. His arguments in the book pointed towards Huxley's prediction of the future that would prevail in the world dominated by visual medium of his day, which is television. Television, argued Postman, sit within the larger entertainment industry that relied on visual appeal (in terms of presentation as well as the people appearing on screen) as well as a mode of communication that is entertaining. As such, the presentation 
of public discourse on television has to adopt and adapt to this characteristic of television-it has to be presented in an entertaining manner, and in the process shriveling public discourse into mere entertainment (with of course, a serious make up!). Because after all, it is not the topic of public discourse that matter more. It is the medium that matters, i.e. to use McLuhan's phrase, the medium is the message.

The dominant medium of today is no longer television but the various social media platforms that are available to us. These platforms are where communications about public life take place, ideas and thoughts of our leaders are made easily accessible, and citizens participated publicly in publis issues. Following Postman's call, we need to ask what these platforms represent and what they took away from us. As more control is given to users (both political actors and followers) to create content related to politics, and as users decide who to listen to (i.e. to follow), politics as performed online may not encourage full participants from citizens.

Arab Spring 2011, Occupy Movement, Black Lives Matter and the "Me Too Movement" are some examples of social movements and activism that have used the various social media platforms in creating global awareness, if not social change, regarding important issues. The success in this regard can be contributed to the role social media platforms played as an important source for information and venue for political debate and discussions. Viewed this way, social media has the capacity to boost political participation among citizens. Yet, insights from Postman as well as the nature of social media may not bring the desired effect in terms of political participation. 
Proceeding ICOGISS 2019

Page 1-8. ISBN: 978-602-6 988-75-1

Web Jurnal Online: jurnal.unmuhjember.ac.id

By: Azrina Husin

Performing Politics In The Age Of Social Media:

Entertainment, Information And Governance

\section{References}

Aaker, Jennifer and Chang, Victoria. 2010. "Obama and the power of social media and technology," in The European Business Review, May-June 2010. https://jaaker.people.stanford.edu/sites/g/files/sbiybj2966/f/tebrmay-juneobama.pdf

Benkler, Yochai. 2006. The Wealth of Networks. New Haven, CT: Yale University Press.

Bernama. "Malaysia ranks top 5 globally in mobile social media penetration, highest in the region," in New Straits Times, 3 July 2019 (online) Retrieved from https://www.nst.com.my/lifestyle/bots/2019/01/456119/malaysia-ranks-top-5globally-mobile-social-media-penetration-highest

Clement, J. 2019. "Number of monthly active Facebook users worldwide as of 1st quarter 2019 (in millions)," in Statista Retrieved from https://www.statista.com/statistics/264810/number-of-monthly-active-facebookusers-worldwide/

Fuch, Christian. 2018. "Industry 4.0: The Digital German Ideology," in Journal for a Global Sustainable Information Society, Vol. 16. No. 1.

Gainous, Jason and Wagner, Kevin, M. Tweeting to Power: The Social Media Revolution in American Politics.

Habermas, Jürgen. 1991. The Structural Transformation of the Public Sphere. An Inquiry into a Category of Bourgeois Society. Cambridge, MA: MIT Press.

Papacharissi, Zizi. 2009. "The Virtual Sphere 2.0. The Internet, the Public Sphere, and Beyond," in Routledge Handbook of Internet Politics, eds. Andrew Chadwick and Philip N. Howard, 230-245. New York: Routledge.

Postman, Neil. 1985. Amusing ourselves to death: Public discourse in the age of show business. Londong: Penguin Book

Shaban, Hamza "Twitter reveal its daily active user numbers for the first time," in the Washington Post. 7 February 2017. Retrieved from https://www.washingtonpost.com/technology/2019/02/07/twitter-reveals-itsdaily-active-user-numbers-first-time/?utm_term $=.34246 \mathrm{dcbbdca}$

Sunden, Jenny. 2003. Material Virtualities: Approaching online textual embodiment. New York: Peter Lang Publishing Inc.

Tuchman, Gaye. 1978. Making news: A study in the construction of reality. New York: The Free Press.

Internet Users Survey 2018: Statistical Brief Number Twenty-Three. Cyberjaya: Malaysian Communications and Multimedia Commission. 